The Condor 109:692-697

(C) The Cooper Ornithological Society 2007

\title{
USING COLOR TO DEFINE SPECIES BOUNDARIES: QUANTITATIVE ANALYSIS IN THE ORCHARD ORIOLE COMPLEX SUPPORTS THE RECOGNITION OF TWO SPECIES
}

\author{
Lynna M. Kiere, Christopher M. Hofmann ${ }^{1}$, Ian E. Tracy, Thomas W. Cronin, Jeff Leips, \\ AND KEVIN E. OMLAND \\ Department of Biological Sciences, University of Maryland, 1000 Hilltop Circle, Baltimore County, Baltimore, \\ $M D 21250$
}

Abstract. The recent divergence of Orchard (Icterus spurius spurius) and Fuertes's Orioles (I. s. fuertesi) makes them an ideal system for investigating species boundaries. Orchard and Fuertes's Orioles differ in several respects. They have distinct breeding ranges-Fuertes's Orioles breed in eastern coastal Mexico, whereas Orchard Orioles breed throughout eastern and central North America-and differ in plumage coloration, with adult male Orchard Orioles appearing "chestnut" and Fuertes's Orioles "ochre." However, no detailed quantitative color analyses have been conducted. To characterize these differences we quantitatively measured plumage color using reflectance spectrometry. The colored plumages of adult male Orchard and Fuertes's Orioles have unique spectral characteristics, with no color overlap between them. Combined with life history differences and previous molecular studies, these findings support the classification of Orchard and Fuertes's Orioles as separate species. Additionally, this study demonstrates the utility of quantitative color measurement as a tool for examining species boundaries.

Key words: Fuertes's Oriole, Icterus spurius fuertesi, Icterus spurius spurius, Orchard Oriole, plumage coloration, reflectance spectrometry, species boundaries.
Utilizando el Color para Definir los Límites de las Especies: El Análisis Cuantitativo de Icterus spurius spurius e I. s. fuertesi Apoya el Reconocimiento de Dos Especies

Resumen. La reciente divergencia de Icterus spurius spurius e I. s. fuertesi hace de ellos un sistema ideal para investigar los límites de las especies, ya que ambos taxones difieren en varios aspectos. Por un lado, tienen diferentes áreas de reproducción. I. $s$. fuertesi se reproduce en la costa este mexicana del Golfo de México (Tamaulipas a Veracruz), mientras que $I$. s. spurius se reproduce por casi todo el este y centro de Norteamérica. También difieren en la coloración del plumaje. Los machos adultos de $I$. $s$. spurius generalmente presentan color castaño, mientras que los machos de I. s. fuertesi son ocres. Sin embargo, no se habían realizado análisis cuantitativos de la coloración. Para caracterizar estas diferencias, usamos espectrometría de reflectancia para medir cuantitativamente el color del plumaje. Encontramos que los plumajes coloreados de los machos adultos de I. S. spurius e I. s. fuertesi tienen características de espectro propias, sin superposición de color entre los taxones. En conjunto con las diferencias en la historia de vida y en los estudios moleculares previos, estas conclusiones apoyan la clasificación de I. spurius e $I$.

Manuscript received 11 July 2006; accepted 15 March 2007.

${ }^{1}$ Corresponding author. E-mail: chofma1@umbc.edu 
fuertesi como especies distintas. Además, esta investigación demuestra la utilidad de las medidas cuantitativas del color como una herramienta para examinar las fronteras de las especies.

Delineating species boundaries is a contentious issue for many avian taxa. A species concept suitable for one group may be inapplicable to another. Orchard (Icterus spurius spurius) and Fuertes's Orioles (I. s. fuertesi) are two closely related New World orioles whose species status is unclear (Baker et al. 2003). No single species concept fully describes this complex, making it an excellent candidate for examination using multiple criteria (de Queiroz 1998, 2005, Sites and Marshall 2003). Our goal was to evaluate this species complex based on new quantitative color data as well as existing life history, ecological, phylogenetic, and molecular information.

Adult male Orchard and Fuertes's Orioles appear to have visually distinct plumage coloration. The Orchard Oriole is described as chestnut, while the Fuertes's Oriole is described as tan or ochre (Jaramillo and Burke 1999). Because the characteristics of adult male plumage seem to be important in female mate choice, differences in male coloration may be evolutionarily significant in these taxa (Enstrom 1993). However, in previous morphological work, Graber and Graber (1954) suggested that there may be clinal variation in color resulting in intergradation between the two taxa. These claims were based on small sample sizes and have not been rigorously tested. In addition to adult male coloration, Orchard and Fuertes's Orioles differ in several aspects of their ecology and life history. For example, they exhibit distinct breeding ranges and migratory behaviors. The Orchard Oriole breeds in the eastern and central United States and central plains of Mexico, whereas the Fuertes's Oriole breeds exclusively from Tamaulipas to Veracruz along the Gulf of Mexico (Fig. 1). The Orchard Oriole is a long-distance migrant with a wintering range extending from Sinaloa and Veracruz south to northern Colombia and Venezuela. The Fuertes's Oriole is a short-distance migrant that winters only from Guerrero to Chiapas on Mexico's Pacific coast (Jaramillo and Burke 1999). In other aspects, however, Orchard and Fuertes's Orioles are similar. Adult male plumage pattern is identical (Omland and Lanyon 2000). Plumage of females and second-year (SY) males is virtually indistinguishable between taxa, although Jaramillo and Burke (1999) suggested that Fuertes's Oriole females may be slightly paler. Standard morphological measurements show considerable overlap in body size between the two taxa; tarsus length of Orchard Oriole males averages $21.6 \mathrm{~mm}$ (range: 20.6$22.9 \mathrm{~mm}$ ) and that of Fuertes's males $21.0 \mathrm{~mm}$ (range: 19.0-25.0 mm). Female Orchard Oriole tarsus length averages $21.6 \mathrm{~mm}$ (range: $20.6-23.1 \mathrm{~mm}$ ) and female Fuertes's $22.0 \mathrm{~mm}$ (range: $22.0-22.0 \mathrm{~mm}$; Jaramillo and Burke 1999). The song of both taxa is also similar, but may be less varied and softer in Fuertes's Orioles (Jaramillo and Burke 1999).

Due to these similarities and differences, the species status of Orchard and Fuertes's Orioles has been controversial. Chapman (1911) first separated the taxa based on differences in breeding range and plumage coloration (Sclater 1939). Later, Blake (1953) classified them as conspecific. More recently, this question has been investigated from a molecular and phylogenetic perspective. Omland et al. (1999) found an average sequence divergence of $0.6 \%$ between Orchard and Fuertes's Oriole cytochrome $b$ and ND2 mitochondrial genes, comparable to the $0.5 \%$ divergence in these genes between Baltimore ( $I$. galbula) and Black-backed Orioles (I. abeillei). Baker et al. (2003) found that some Orchard and Fuertes's Oriole individuals shared mtDNA haplotypes, indicating that they were not reciprocally monophyletic; however, significant haplotype frequency differences suggested little or no gene flow between the taxa. Thus, they concluded that Orchard and Fuertes's Orioles represent a case of recent divergence with lack of reciprocal monophyly due to incomplete lineage sorting (Baker et al. 2003).

Our major objectives were to use coloration to clarify species status in these taxa by: 1) quantitatively measuring the adult male plumage coloration of Orchard and Fuertes's Orioles and determining whether there are significant differences between taxa; 2) comparing the variation among geographically separated populations within each taxon to the variation between the taxa; and 3) examining whether there is evidence of clinal variation in color.

\section{METHODS}

\section{SPECIMEN SELECTION}

We sampled adult male Orchard and Fuertes's Orioles from multiple parts of their breeding ranges to look for evidence of overlap in coloration between taxa and to examine whether there were geographical differences in plumage reflectance within each taxon. Specimens were obtained from museum collections (Smithsonian National Museum of Natural History, Delaware Museum of Natural History, Field Museum of Natural History, and American Museum of Natural History) and selected based on collection locality. We sampled five adult (after-second-year) male individuals per population for each taxon (a total of 15 Orchard and 10 Fuertes's Orioles). Adult males are easily distinguished from females and SY males because of sexual dichromatism and delayed plumage maturation (females are olive on the upperparts and tail and yellow below; SY males are similar in coloration to females with the addition of a black throat patch; Jaramillo and Burke 1999). We chose Orchard Orioles collected from three geographic regions of their breeding range: one in the northeast, one in the northwest, and one in the southwest (Fig. 1). Fuertes's Orioles were chosen from the northern and southern regions of their breeding range (Tamaulipas and Veracruz, respectively; Fig. 1). We chose these particular geographic sampling regions because they are at the extremes of each taxon's range. If any clinal variation is indeed present, it should be most apparent between these regions, where populations are separated by the greatest geographical distance. To ensure that we scored breeding rather than migrating Orchard Orioles, we only measured specimens collected from 


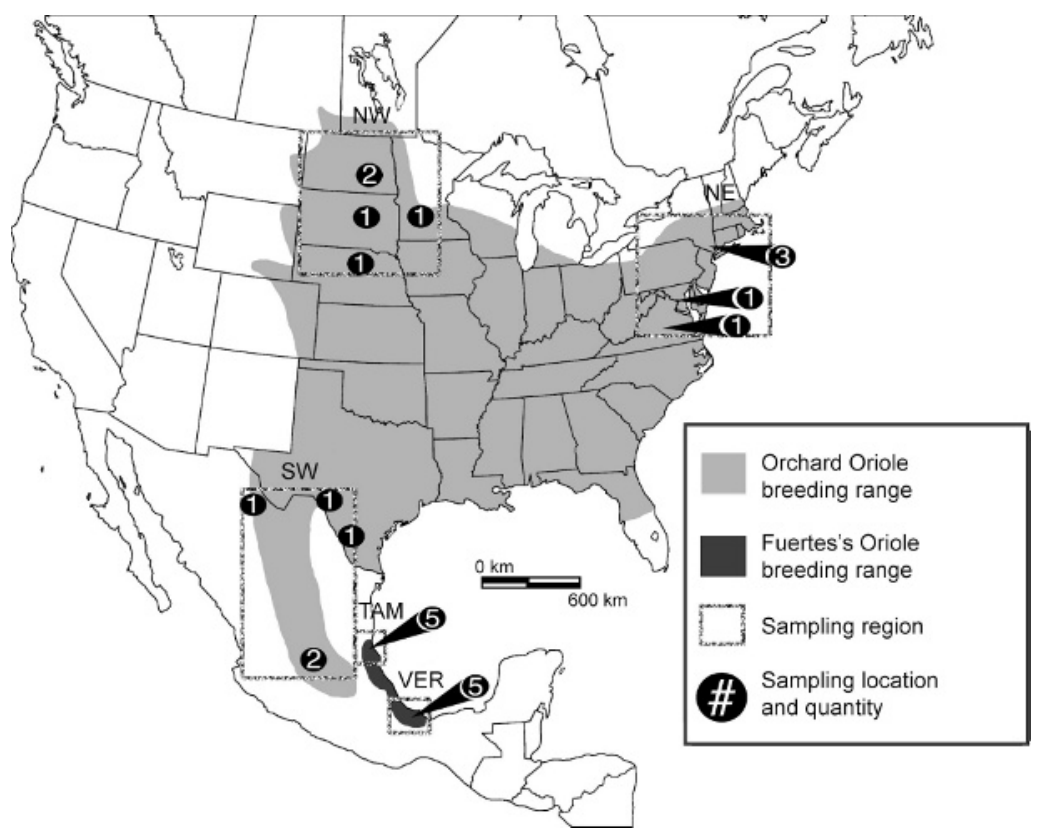

FIGURE 1. Map showing breeding ranges, sampling regions, and number of specimens of Orchard and Fuertes's Orioles collected from each location within sampling regions. For the Fuertes's Oriole, sampling regions are Tamaulipas (TAM) and Veracruz (VER). Breeding ranges are from Jaramillo and Burke (1999).

May to early August (Scharf and Kren 1996; Appendix).

\section{COLOR MEASUREMENT}

Oriole plumage color was measured with an Ocean Optics (Dunedin, Florida) USB 2000 spectrometer and a full spectrum Xenon light source (Ocean Optics PX-2) following methods described in Hofmann et al. (2006, 2007). The data provided by the reflectance spectrometer are well suited to this type of study because they are objective, quantitative (Sites and Marshall 2003), and free from the bias of the human visual system (Bennett et al. 1994). All spectra were measured relative to the dark and a Spectralon diffuse white standard (Labsphere, North Sutton, New Hampshire), and the spectrometer was standardized between specimens. Due to subtle color differences between different body regions of Fuertes's Orioles, we measured all major colored body regions: breast, epaulet, rump, and belly (Hofmann et al. 2007). We took three replicate nonoverlapping measurements of each body region perpendicular to the plumage surface of each specimen (Hofmann et al. 2006, 2007).

\section{STATISTICAL ANALYSES}

We grouped raw spectral data into $1 \mathrm{~nm}$ increments using custom-designed software (CMH, TWC, and T.-H. Chiou, unpubl. data). Replicate spectra were then averaged for each individual over the conservative avian visual range of 300-700 nm (Hart 2001). We derived three colorimetric variables from spectral data: spectral location (wavelength at 50\% of maximum reflectance), average brightness (average reflectance over the $300-700 \mathrm{~nm}$ range), and red chroma (reflectance from $600-700 \mathrm{~nm}$ divided by total reflectance; Montgomerie 2006). These values correspond to the visually important color characteristics of hue, brightness, and saturation. For each variable, we performed a nested ANOVA with population nested within taxon to examine differences among populations within each taxon and differences between the two taxa. To address the possibility of geographic differences not detected by nested ANOVA, we also performed linear regressions of spectral location, average brightness, and red chroma of breast plumage as functions of collection latitude for both taxa. Though colorimetric attributes represent important aspects of color perception, they may not capture the full extent of variation across the reflectance spectrum; therefore, we also performed repeated measures ANOVA on reflectance values at $50 \mathrm{~nm}$ intervals from 300 to $700 \mathrm{~nm}$.

For Orchard Orioles, the year of collection of available specimens varied greatly, with specimens collected as early as 1890 and as recently as 1948 (Appendix). To examine whether our results were influenced by degradation of plumage during storage, we performed linear regressions of our three colorimetric variables as functions of year of collection. ANOVAs were performed with SAS version 9.1 (SAS Institute 2003), and linear regressions were done using SPSS version 15.0 (SPSS 2006). 


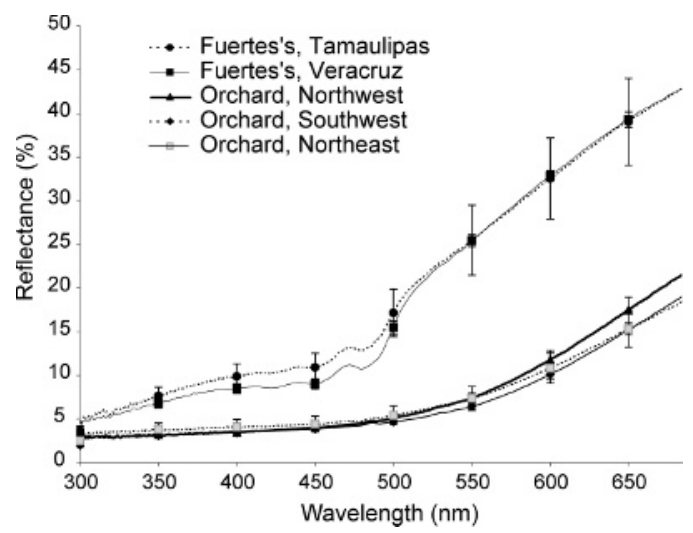

FIGURE 2. Average reflectance of breast plumage over the avian visual spectrum for Orchard and Fuertes's Orioles grouped by geographic sampling region (Fig. 1). Note that there is no spectral overlap between taxa, and that most of the variation occurs between taxa rather than among populations. Error bars represent SE.

\section{RESULTS}

The colored plumage of Orchard and Fuertes's Orioles produced characteristically different reflectance spectra. Orchard Oriole spectra were typical of phaeomelanin-based colors (Hofmann et al. 2007), with reflectance increasing gradually from 300 to $700 \mathrm{~nm}$. Orchard Oriole spectra had lower reflectance than Fuertes's Oriole spectra at all wavelengths. The reflectance spectra for Fuertes's Orioles exhibited a shape intermediate between typical melanin and typical carotenoid spectra (see Hofman et al. [2007] for further discussion of the proximate basis of melanin and carotenoid use in colored plumage of Orchard and Fuertes's Orioles). There was minor increase in Fuertes's Oriole plumage reflectance in the UV range until around $400 \mathrm{~nm}$, a small peak around $470 \mathrm{~nm}$, then a sharper increase to the highest reflectance value at $700 \mathrm{~nm}$ (Fig. 2).

Nested ANOVA revealed highly significant differences between the two taxa in all three colorimetric variables (Table 1), while indicating that there were no significant differences among populations within each taxon (Table 1). Further supporting these results, linear regressions found no significant re- lationships between collection latitude and colorimetric variables in Orchard Orioles (spectral location: $r=0.34, P=0.21$; average brightness: $r=0.22$, $P=0.43$; red chroma: $r=0.01, P=0.96$ ) or Fuertes's Orioles (spectral location: $r=0.21, P=$ 0.57 ; average brightness: $r=0.02, P=0.96$; red chroma: $r=0.34, P=0.34$ ).

Repeated measures ANOVA found highly significant differences between reflectance spectra of the two taxa for all body regions (Table 2). Further support for this result is provided by the lack of overlap of average spectra of the two taxa, regardless of the body regions or populations being compared (Fig. 2).

In considering the possible effect of plumage degradation due to storage of specimens, linear regressions showed no significant relationship between year of collection and spectral location $(r=$ $0.50, P=0.07)$, average brightness $(r=0.36, P=$ $0.21)$, or red chroma $(r=0.06, P=0.83)$. Furthermore, any possible trends suggested that older Orchard Oriole specimens were more similar to Fuertes's Orioles, rather than more different. Therefore, even if there were a slight change in coloration due to aging of specimens, it would not artificially inflate differences between these taxa.

\section{DISCUSSION}

Our study provides strong quantitative data suggesting that there is no overlap in color between adult male Orchard and Fuertes's Orioles. Furthermore, differences between taxa explained the majority of the variation that we measured. Thus, our findings for color are similar to Baker et al.'s (2003) molecular results, which suggested that the majority of genetic variation was occurring between taxa.

Contrary to Graber and Graber's (1954) suggestion, we found no evidence of a north-south gradient or any other clinal variation in color for either taxon. Though we did find some regional variation among Orchard Orioles, these differences did not appear to be statistically significant given our sample size and methods of analysis, and did not show a north-south trend. Although the individuals from the northeast population appeared slightly darker (indicated by a slightly lower percent reflectance overall), the northwest and southwest populations appeared virtually identical for all body regions. If a northto-south gradient were present, then we would have expected both the northeast and northwest populations to have darker plumage, and the southwest

TABLE 1. Results of the nested ANOVA (population nested within taxon) performed on colorimetric variables of breast plumage reflectance of Orchard and Fuertes's Orioles. Differences between taxa are significant for all three variables, while differences among populations within taxa are not significant.

\begin{tabular}{|c|c|c|c|c|c|c|c|c|c|}
\hline & \multicolumn{3}{|c|}{ Spectral location } & \multicolumn{3}{|c|}{ Average brightness } & \multicolumn{3}{|c|}{ Red chroma } \\
\hline & $F$ & $P$ & $r^{2}$ & $F$ & $P$ & $r^{2}$ & $F$ & $P$ & $r^{2}$ \\
\hline Between taxa & 218.0 & $<0.001$ & 0.91 & 174.5 & $<0.001$ & 0.89 & 18.2 & $<0.001$ & 0.40 \\
\hline Among populations within taxa & 0.5 & 0.69 & 0.01 & 0.2 & 0.92 & $<0.01$ & 2.4 & 0.10 & 0.16 \\
\hline
\end{tabular}


TABLE 2. Results of the repeated measures ANOVA comparing plumage reflectance spectra of Orchard and Fuertes's Orioles from all sampled populations at $50 \mathrm{~nm}$ intervals across the avian visual range $(300-700 \mathrm{~nm})$.

\begin{tabular}{lcc}
\hline \hline Body region & $F_{9,15}$ & $P$ \\
\hline Breast & 82 & $<0.001$ \\
Epaulet & 27 & $<0.001$ \\
Rump & 47 & $<0.001$ \\
Belly & 51 & $<0.001$ \\
\hline
\end{tabular}

population to have lighter plumage, more similar to or possibly overlapping that of the Fuertes's Orioles. Furthermore, Hofmann et al. (2007) demonstrated that the color difference between these two taxa is due to a large difference in phaeomelanin pigment concentration (close to an order of magnitude in ventral body feathers), which suggests a genetic difference rather than dietary influences or phenotypic plasticity. While continued investigation of geographic variation within the Orchard Oriole remains an interesting avenue for further research, our data do not support the hypothesis that northsouth clinal variation is responsible for the major differences in color between Orchard and Fuertes's Orioles.

\section{TAXONOMIC IMPLICATIONS: USING MULTIPLE CRITERIA}

Previous genetic studies (Omland et al. 1999, Baker et al. 2003), differences in migratory behavior and geographic range (Jaramillo and Burke 1999), and our results showing quantitative plumage color differences provide multiple criteria supporting the elevation of Orchard and Fuertes's Orioles to full species status (de Queiroz 1998, 2005, Helbig et al. 2002). At present, two checklists have already recognized these taxa as distinct species (Clements 2000, Navarro-Sigüenza and Peterson 2004). An important implication of full species status for the Fuertes's Oriole is the potential need for conservation measures. The Orchard Oriole has experienced significant population declines in Oklahoma and Texas since the 1960s due to habitat loss, to the extent of being considered a "Species of Special Concern" by the National Audubon Society's American Birds Blue List in the 1980s (Oberholser 1974, Tate 1986, Scharf and Kren 1996). Though no population data are currently available for Fuertes's Orioles, loss or alteration of their habitat on a large scale could have a dramatic effect due to their limited breeding range. Elevation to species status might provide a greater impetus to evaluate the conservation status of Fuertes's Orioles through studies of behavior, breeding ecology, distribution, and population sizes.

Our thanks go to the Omland lab for general support. Maria Nandadevi Cortez-Rodriguez and Hernan Vazquez-Miranda provided excellent feedback on speciation in the production of this manuscript. Tsyr-Huei "Short" Chiou was invaluable in his knowledge of electronics. Ryan Ihnacik helped with obtaining literature citations. We thank The Smithsonian National Museum of Natural History, Delaware Museum of Natural History, The Field Museum of Natural History, and The American Museum of Natural History for use of specimens. IET was supported by the Arnold and Mabel Beckman Foundation and an undergraduate research grant from the University of Maryland, Baltimore County. KEO was supported by National Science Foundation (NSF) grant DEB-0347083. LMK was supported by an NSF Research Experiences for Undergraduates supplement to that grant.

\section{LITERATURE CITED}

Baker, J. M., E. López-Medrano, A. G. NAVARRO-SIGÜENZA, O. R. RoJAS-SOTO, AND K. E. OMLAND. 2003. Recent speciation in the Orchard Oriole group: divergence of Icterus spurius spurius and Icterus spurius fuertesi. Auk 120:848-859.

Bennett, A. T., I. C. Cuthill, And K. J. Norris. 1994. Sexual selection and the mismeasure of color. American Naturalist 144:848-860.

Blake, E. R. 1953. Birds of Mexico. University of Chicago Press, Chicago.

Chapman, F. M. 1911. Description of a new oriole (Icterus fuertesi) from Mexico. Auk 28:1-4.

Clements, J. F. 2000. Birds of the world: a checklist. Ibis Publishing, Vista, CA.

DE QUEIROZ, K. 1998. The general lineage concept of species, species criteria, and the process of speciation: conceptual unification and terminological recommendations, p. 57-75. In D. J. Howard and S. H. Berlocher [EDS.], Endless forms: species and speciation. Oxford University Press, Oxford, UK.

DE QueIroZ, K. 2005. A unified concept of species and its consequences for the future of taxonomy. Proceedings of the California Academy of Sciences 56:196-215.

EnSTROM, D. A. 1993. Female choice for age-specific plumage in the Orchard Oriole: implications of delayed plumage maturation. Animal Behaviour 45:435-442.

Graber, R. R., AND J. W. Graber. 1954. Comparative notes on Fuertes's and Orchard Orioles. Condor 56:274-282.

HART, N. S. 2001. The visual ecology of avian photoreceptors. Progress in Retinal and Eye Research 20:675-703.

Helbig, A. J., A. G. Knox, D. T. Parkin, G. SAngster, And M. Collinson. 2002. Guidelines for assigning species rank. Ibis 144:518-525.

Hofmann, C. M., T. W. CROnin, AND K. E. OMLAND. 2006. Using spectral data to reconstruct evolutionary changes in coloration: carotenoid color evolution in New World orioles. Evolution 60:1680-1691.

Hofmann, C. M., K. J. McGraw, T. W. Cronin, AND K. E. OMLAND. 2007. Melanin coloration in New World orioles. I: carotenoid masking and pigment dichromatism in the Orchard Oriole complex. Journal of Avian Biology, in press. 
Jaramillo, A., And P. Burke. 1999. New World blackbirds. Princeton University Press, Princeton, NJ.

Montgomerie, R. 2006. Analyzing colors, p. 90147. In G. E. Hill and K. J. McGraw [EDS.], Bird coloration. Vol. I: Mechanisms and measurements. Harvard University Press, Cambridge, MA.

Navarro-Sigüenza, A. G., And A. T. Peterson [online]. 2004. An alternative species taxonomy of Mexican birds. Biota Neotropica v4 (n2). $<$ http://www.biotaneotropica.org.br/v4n2/pt/ abstract?taxonomic-review+BN03504022004> (10 May 2006).

Oberholser, H. C. 1974. The bird life of Texas. University of Texas Press, Austin, TX.

OMLAND, K. E., AND S. M. LANYON. 2000. Reconstructing plumage evolution in orioles (Icterus): repeated convergence and reversal in patterns. Evolution 54:2119-2133.

Omland, K. E., S. M. Lanyon, and S. J. Fritz. 1999. A molecular phylogeny of the New World orioles (Icterus): the importance of dense taxon sampling. Molecular Phylogenetics and Evolution 12:224-239.

SAS Institute. 2003. SAS system for Windows. Version 9.1. SAS Institute, Inc., Cary, NC.

SCHARF, W. C., AND J. KREN. 1996. Orchard Oriole (Icterus spurius). In A. Poole and F. Gill [EDS.], The birds of North America, No. 255. The Academy of Natural Sciences, Philadelphia, PA, and The American Ornithologists' Union, Washington, DC.

SClATER, W. L. 1939. A note on some American orioles of the family Icteridae. Ibis 1939:140 145 .

Sites, J. W., JR., And J. C. Marshall. 2003. Delimiting species: a renaissance issue in systematic biology. Trends in Ecology \& Evolution 18:462-470.

SPSS. 2006. SPSS 15.0 for Windows. Release 15.0.0. SPSS, Inc., Chicago.

TATE, J., JR. 1986. The Blue List for 1986. American Birds 40:227-236.

APPENDIX. Catalogue numbers and collection information for museum specimens of Orchard (Icterus spurius spurius) and Fuertes's Orioles (I. s. fuertesi) measured for quantitative plumage color analyses. See Figure 1 for locations of sampling regions; TAM = Tamaulipas, VER = Veracruz.

\begin{tabular}{|c|c|c|c|c|}
\hline Taxon & Voucher number ${ }^{\mathrm{a}}$ & Region & Collection locality & Collection date \\
\hline I. s. spurius & NMNH-441258 & $\mathrm{NE}$ & New York, New York & 20 May 1905 \\
\hline I. s. spurius & NMNH-441259 & $\mathrm{NE}$ & New York, New York & 20 May 1905 \\
\hline I. s. spurius & NMNH-441262 & $\mathrm{NE}$ & Overpeck Creek, New York & 4 August 1917 \\
\hline I. s. spurius & NMNH-525184 & $\mathrm{NE}$ & Virginia & 30 May 1901 \\
\hline I. s. spurius & NMNH-593363 & $\mathrm{NE}$ & Prince Georges County, Maryland & 29 April 1945 \\
\hline I. s. spurius & NMNH-4746 & NW & Nebraska & 14 May 18-- \\
\hline I. s. spurius & NMNH-125162 & NW & Minnesota & 3 June 1890 \\
\hline I. s. spurius & NMNH-239315 & NW & North Dakota & 26 June 1912 \\
\hline I. s. spurius & NMNH-259433 & NW & Fairmount, North Dakota & 24 May 1915 \\
\hline I. s. spurius & FMNH-327743 & NW & South Dakota & 3 June 1942 \\
\hline I. s. spurius & DMNH-23345 & SW & Chihuahua, Mexico & 2 May 1972 \\
\hline I. s. spurius & DMNH-23354 & SW & Chihuahua, Mexico & 1 May 1972 \\
\hline I. s. spurius & DMNH-44197 & SW & Michoacan, Mexico & 21 May 1948 \\
\hline I. s. spurius & NMNH-144442 & SW & Lagas, Jalisco, Mexico & 29 June 1896 \\
\hline I. s. spurius & NMNH-364820 & SW & Del Rio, Texas & 16 June 1939 \\
\hline I. s. fuertesi & DMNH-44146 & TAM & Altamira, Tamaulipas, Mexico & 22 June 1953 \\
\hline I. s. fuertesi & DMNH-44147 & TAM & Tampico, Tamaulipas, Mexico & 2 May 1949 \\
\hline I. s. fuertesi & DMNH-44149 & TAM & Loma del Real, Tamaulipas, Mexico & 18 June 1953 \\
\hline I. s. fuertesi & DMNH-44150 & TAM & Moron, Tamaulipas, Mexico & 4 July 1953 \\
\hline I. s. fuertesi & AMNH-818293 & TAM & Lapesco, Tamaulipas, Mexico & 4 July 1970 \\
\hline I. s. fuertesi & DMNH-40009 & VER & Tlacotalpan, Veracruz, Mexico & 6 January 1962 \\
\hline I. s. fuertesi & FMNH-299995 & VER & Tlacotalpan, Veracruz, Mexico & 6 March 1962 \\
\hline I. s. fuertesi & AMNH-818302 & VER & Tlacotalpan, Veracruz, Mexico & 3 April 1964 \\
\hline I. s. fuertesi & AMNH-818304 & VER & Tlacotalpan, Veracruz, Mexico & 22 March 1964 \\
\hline I. s. fuertesi & AMNH-818310 & VER & Tlacotalpan, Veracruz, Mexico & 3 April 1962 \\
\hline
\end{tabular}

${ }^{a}$ Museums are abbreviated as follows: DMNH = Delaware Museum of Natural History, NMNH = Smithsonian National Museum of Natural History, AMNH = American Museum of Natural History, $\mathrm{FMNH}=$ Field Museum of Natural History. 